\title{
When Corporate Social Responsibility Matters: An Empirical Investigation of Contingencies
}

NOTE: This is the pre-proof manuscript version. For the final published version, please see:

http://inderscience.metapress.com/content/q2064403x0pt9706/

\section{Citation Information:}

Luxmore, S. R., Tang, Z., \& Hull, C. E. (2012). When corporate social responsibility matters: an empirical investigation of contingencies. International Journal of Corporate Governance, $3(2), 143-162$.

\begin{abstract}
Rather than re-examine the question of whether doing good generally helps a company to do well, this study draws on contingency theory to empirically examine when doing good helps a company do as well as possible. Using panel data, we examine the effects of industry life cycle, munificence, and instability on the relationship between corporate social responsibility (CSR) and corporate financial performance (CFP). Our findings indicate that life cycle has a significant impact on the CSR-CFP relationship, as does industry instability. These findings suggest that CSR helps the bottom line considerably - if it is applied at the right time.
\end{abstract}




\section{Introduction}

Is doing good its own reward or does doing good lead to doing well? This question is at the root of the debate over corporate social responsibility (CSR). A more nuanced version of the question has evolved from that debate: Under what circumstances does doing good lead to doing well? The study of CSR continues to evolve as there is no consensus on empirical methodology, theoretical frameworks, or CSR measurement (Ditlev-Simonsen and Gottschalk, 2011; McWilliams, Siegel, and Wright, 2006; Surroca, Tribo, and Waddock, 2010). There is, however, a standard research question as to the strategic role of CSR: "Do CSR initiatives lead to improved performance?" There have been CSR initiatives which have done so, and others which have not, or which have even hurt performance. Our question, thus, is not whether CSR initiatives lead to improved performance, but when CSR initiatives benefit corporate financial performance (CFP) - and when they do not.

The primary purpose of our study is to broaden our understanding of CSR's financial impact by applying the contingency perspective to the insights offered by the resource-based view (RBV). By doing so, we hope to present a clearer picture of how and under what circumstances CSR affects firm CFP. Given the longstanding contention over the CSR-CFP relationship, it is unlikely that this study can by itself resolve the question. But we hope that our findings help researchers better understand this complex relationship, and that we will have helped with the eventual resolution of the important and hotly-debated CSR-CFP relationship.

There are three possible effects of CSR on firm competitiveness: positive, negative, and neutral. Each possible effect enjoys both theoretical justification and supporting empirical evidence. Lee (2008) notes that over 30 years of research has failed to identify a definitive CSRperformance link. The discrepancy in findings may be attributed to competing theories, 
methodologies and measurement issues (Ditlev-Simonsen and Gottschalk, 2011; Hull and Rothenberg, 2008; Lee, 2008; Lockett, Moon, and Visser, 2006; Margolis and Walsh, 2003; McWilliams and Siegel, 2001; McWilliams, Siegel, and Wright, 2006; Orlitzky, Schmidt, and Rynes, 2003; Russo and Fouts, 1997; Surroca, Tribo, and Waddock, 2010; Wood, 2010; Wood and Jones, 1995).

Research that has found a positive CSR-CFP relationship suggests that factors such as improved stakeholder relationships, reduced HRM costs due to improved employee recruitment and performance, enhanced quality, and better market opportunities are the underlying causes of this outcome (Becchetti, Di Giacomo, and Pinnacchio, 2008; Hull and Rothenberg, 2008; McWilliams, Siegel, and Wright, 2006). Meta-analyses by Margolis and Walsh (2003) and Orlitzky, Schmidt, and Rynes (2002) found empirical support for a positive CSR-performance result. Thus, in this paper, we accept the notion that higher levels of CSR in general should lead to better CFP. However, we also accept the premise that there may be circumstances in which the effects of CSR on CFP are reduced. As these circumstances appear to extend across multiple firms at one time, potentially explaining the variance in different studies of the phenomenon (Lee, 2008), it seems likely that these circumstances are environmental rather than firm-specific.

The firm strategy-performance relationship is heavily affected by environmental contingency factors (Argyres and Bigelow, 2007; Keats and Hitt, 1988; Robinson and McDougall, 2001). This holds true for CSR as a specific strategic initiative: McWilliams and Siegel (2001) suggest that advertising and incomes positively moderate the demand for CSR activity. Surroca, Tribo, and Waddock (2010) find support for growth as a moderating effect on CSR and CFP in their virtuous circle model. Becchetti, Di Giacomo, and Pinnacchio (2008) 
include business cycle as a moderating factor, but do not report empirical data for it. They measure business cycle by year; thus what they measure is not industry life cycle.

Industry life cycle has been discussed as an influential external factor affecting the CSRperformance relationship (McWilliams and Siegel, 2001; Surroca, Tribo, and Waddock, 2010), but so far no study has thoroughly investigated such an effect. McWilliams, Siegel, and Wright (2006) call for the empirical testing of the effects of industry life cycle on CSR. In a paper unrelated to CSR, Lumpkin and Dess (2001) include munificence and instability (dynamism) with industry life cycle as moderating factors to the strategic choice of aggressiveness and proactiveness. While not every hypothesis was supported, their results do indicate that all three moderating factors have an effect on the strategy-performance relationship, and thus should be included in our study of the strategic choice of CSR and its effects on CFP. Industry life cycle is an environmental variable that has great potential to explain varying effects of any strategy on performance. However, including munificence and instability in any study that includes industry life cycle captures aspects of the environment which are not directly related to the life cycle, thus giving us a better understanding of the impact of the environment on the CSR-CFP relationship. Surroca, Tribo, and Waddock (2010) included industry growth in their model, but did not conduct their study using the concept of munificence.

Based on our theoretical models, we include the industry life cycle and environmental munificence and instability as contingency conditions in our investigation of the CSR-CFP relationship. Drawing upon the RBV, we investigate the CSR-CFP relationship over the introduction, growth, and maturity stages of the industry life cycle and during conditions of munificence and instability. 
The next section includes a brief discussion of the RBV and the contingency conditions: industry life cycle, munificence, and instability. Prior CSR empirical studies are reviewed briefly, followed by the development of five hypotheses. The methodology and empirical results follow, with a discussion of the implications of our findings and potential future research directions concluding the paper.

\section{Theories and prior CSR research}

We draw upon several research streams: the resource-based view, the contingency perspective (i.e., environmental munificence and instability), and the industry life cycle model. In this section we review the literature, beginning with the resource-based view.

\subsection{Resource-based View in CSR Research}

The resource-based view (RBV) is integral to understanding firm performance (Barney, 1991, 2001; Branco and Rodrigues, 2006; Surroca, Tribo, and Waddock, 2010), yet is not independent of the external environment. There is a clear link "between the competitive environment and firm capabilities" (Russo and Fouts, 1997, p. 536) which influences optimal resource and capability development and thus performance. A capability is a core competency because it is valued in the marketplace and difficult for competitors to reproduce (Barney, 1991), so the state of that marketplace and the stage of the industry life cycle - which affects competitive behaviour - are important to an RBV understanding of any potential core competency. Our focus on CSR strategies within specific environmental conditions fits this approach. CSR represents a capability which, depending on environmental circumstances, such as the stage in the industry life cycle, may or may not be valuable, rare, and hard to replicate. 
The RBV stresses the role of intangible resources and capabilities as sources of competitive advantage (Barney, 1991; Branco and Rodrigues 2006; Russo and Fouts, 1997; Surroca, Tribo, and Waddock, 2010). RBV research has led to an understanding that competitive advantage arises from such competencies as innovation, corporate culture dimensions, reputation and human resources (Surroca, Tribo, and Waddock, 2010). CSR may be considered a more recently recognized source of advantage as firms develop competencies to address social and ecological concerns (Surroca, Tribo, and Waddock, 2010; Vanhamme and Grobben, 2009). Branco and Rodrigues (2006) identify several means by which CSR may improve performance, including human resource enhancement, product and process innovation, and bolstered corporate reputation. The "uniqueness [of CSR strategies] may serve as a basis for setting the firm apart from its competitors and, accordingly, its competitive advantage" (Carroll and Shabana, 2010, p. 98). Indeed, McWilliams and Siegel (2001) identify CSR as a distinct differentiation strategy, as well as a contributing factor to product and process innovations that lead to differentiation.

\subsection{Industry Life Cycle}

Industry life cycle is a concept drawn from contingency theory to explain CFP and product market performance (Argyres and Bigelow, 2007; Robinson and McDougall, 2001) as well as firm survival (Agarwal and Bayus, 2004; Lee, 2009). The central thesis of the industry lifecycle perspective is that strategic choice and firm performance are influenced by competitive dynamic factor changes that result from the industry cycling through stages (Agarwal and Bayus, 2004;

Argyres and Bigelow, 2007; Agarwal, Sarka, and Echambadi, 2002; Ganco and Agarwal, 2008; Hofer, 1975; Jawahar and McLaughlin, 2001; Lee, 2009; Lumpkin and Dess, 2001; St John, Pounder, and Cannon, 2003). Factors such as entry and exit barriers, economies of scale, and 
innovation vary throughout the industry life cycle creating opportunities and challenges to incumbent and new entrant firms (Agarwal, Sarka, and Echambadi, 2002). Hofer (1975) proposed that optimal strategies are contingent upon product life cycles, which exhibit an evolutionary path quite similar to an industry life cycle. The concept has been extended to industry cycle analysis (Argyres and Bigelow, 2007). Agarwal, Sarka, and Echambadi (2002) corroborate the importance of industry life cycle to evolving and changing competitive environments, particularly barriers to entry, which affect firm performance. In general the earliest stages of the industry life cycle, introduction, is typified by relatively low entry barriers and significant product innovation. The next stage, growth, may see product innovation start to decline as the value of an existing version of the product, and profit, increase. The growth stage typically does involve some product innovation, however, and competition is generally not yet as fierce as it will become when growth ends and the mature stage begins. The mature stage is characterized by increasing entry barriers due to price competition, a resulting emphasis on cost and economies of scale, process innovation, and product quality demands (Agarwal, Sarka, and Echambadi, 2002; Argyres and Bigelow, 2007; Ganco and Agarwal, 2008; Jawahar and McLaughlin, 2001; Lumpkin and Dess, 2001; St John, Pounder, and Cannon, 2003). Lee (2009) indicates firm strategies may change across the stages of the industry life cycle.

As discussed, our approach integrates the RBV with the contingency perspective, including the life cycle perspective, to capture the effects of different environmental conditions on the relative value of CSR, which is to say its impact on firm performance (Barney, 1991, 2001; Branco and Rodrigues, 2006; Surroca, Tribo, and Waddock, 2010). According to the RBV, superior deployment of bundles of internal resources and capabilities is the most significant determinant of performance, while environmental conditions moderate strategy effectiveness. 
We are assessing CSR as a specific bundle of resources and capabilities which may have different effects on firm performance in different stages of the industry life cycle.

\subsection{Munificence and Instability}

Environmental munificence and instability, or dynamism, are both industry factors that may affect strategy and firm performance (Dess and Beard, 1984; Dollinger and Golden, 1992; McArthur and Nystrom, 1991; Palmer and Wiseman, 1999; Sutcliff, 1994). Defined as the ability of an environment to support growth and the degree of resource abundance (Dollinger and Golden, 1992; McArthur and Nystrom, 1991; Palmer and Wiseman, 1999; Sutcliff, 1994), munificence is expected to support greater managerial discretion. Palmer and Wiseman (1999) argue that higher levels of munificence lead to firms undertaking greater risk in their efforts to capture larger portions of industry resources. Su, Xie, and Li (2009) maintain resources are more easily acquired under higher levels of environmental munificence. Thus strategies may be more varied, and a larger number and variety of firms, including those with fewer internal resources, will be able to implement a greater number of strategic initiatives, including CSR. As the level of munificence decreases, firms with fewer internal resources will focus on survival strategies (Dollinger and Golden, 1992).

Dynamism measures the rate of change in the task environment and is expressed as the degree of stability/instability (Dess and Beard, 1984; Harris, 2004; Keats and Hitt, 1988; McArthur and Nystrom, 1991; Su, Xie, and Li, 2009). Instability increases uncertainty: uncertainty about information and interpretation and the resulting diminished capability to identify cause-effect relationships (Lumpkin and Dess, 2001). McArthur and Nystrom (1991) find dynamism affects industry returns as well as the strategy-performance relationship. For 
example inventory turnover has a greater effect on performance for firms in more dynamic industries. Su, Xie, and Li (2009) maintain that dynamic competitive situations act to shorten product life cycles and result in innovation as a key determinant of firm performance. Firms that have quick response capabilities should exhibit superior performance. Dollinger and Golden (1992) indicate firms will attempt to minimize risk as stability increases, and that the threat of instability intensifies with strategic inflexibility.

Thus munificence and dynamism, or instability, affect both strategic behaviour, such as CSR initiatives, and the outcomes of such behaviour, making them obvious potential moderators for the CSR-CFP relationship. An industry could experience different levels of munificence and instability at each stage of the life cycle. When considering environmental factors that might moderate the value of a competency, such as CSR, it is important to include munificence and instability as well as life cycle stage in which a company finds itself.

\subsection{Prior CSR Research}

CSR is positively related to CFP due to factors such as improved stakeholder relationships, reduced costs, improved employee recruitment and performance, bolstered reputations, enhanced quality, and better market opportunities (Becchetti, Di Giacomo, and Pinnacchio, 2008; Hull and Rothenberg, 2008; McWilliams, Siegel, and Wright, 2006; Vanhamme and Grobben, 2009). This approach is consistent with the RBV (McWilliams, Siegel, and Wright, 2006), which treats intangibles as a source of competitive advantage. The knowledge needed to strategically employ CSR at an apposite time and magnitude could be considered an intangible and direct potential source of competitive advantage. Other researchers have proposed CSR as an indirect source of competitive advantage, as CSR will improve the use of other resources (Orlitzky, Schmidt, and 
Rynes, 2003). Meta-analysis studies by Margolis and Walsh (2003) and Orlitzky, Schmidt, and Rynes (2002) indicate empirical evidence supports the positive CSR-CFP result.

Surroca, Tribo, and Waddock (2010) consider growth conditions as a moderating factor, which might overlap with the growth stage of the industry life cycle, but do not address the other two periods (i.e., introductory and mature stages) included in our study. Surroca, Tribo, and Waddock (2010) note this limitation and call for other contingency factors to be included in future research, noting that a broad contingency approach has not been applied to CSR-CFP studies; we address this in the present study. Ditlev-Simonsen and Gottschalk (2011) present a theoretical model that suggests first movers and followers will see different results from their CSR, but their focus is more on understanding measurement issues of CSR in general than on the significance of different stages of the industry life cycle.

McWilliams and Siegel (2001) discuss industry life cycle effects, but tangentially, and they do not develop a hypothesis concerning the life cycle conditions. They discuss how CSR may differ over the industry life cycle, but do not test their propositions. McWilliams, Siegel and Wright (2006) call for industry life cycle to be tested as a moderating factor in the CSR-CFP research. In a conceptual study Jawahar and McLaughlin (2001) consider the organizational life cycle, which has implications for our study: they distinguish among firm types based upon the stage of the organizational life cycle and propose relationships based upon firm capabilities and resources and CSR. However, their study is not empirical and considers organizational rather than industry life cycle. Becchetti, Di Giacomo, and Pinnacchio (2008) measure CSR firm performance over a long period and include a dummy variable to capture year effects, which they argue is a business cycle factor. Their business cycle captures cyclical variations but not industry cycle effects. While there could be some overlap to these two effects, it could be random, and 
their approach does not control for industry cycle conditions. Nor do they report the results of the business cycle. In their study of the effects of R\&D intensity on CSR, Padgett and Galan (2010) find a positive relationship, indicating firms with higher levels of R\&D engage in higher levels of CSR, and infer from this that R\&D should be a consideration in CSR financial performance studies. Our study controls for R\&D directly and through the industry life cycle as R\&D intensity is known to change over the life cycle (Agarwal, Sarka, and Echambadi, 2002). Industry growth is included by Russo and Fouts (1997) in their study of the effect of corporate environmental performance on firm performance. We expand on their study by including measures of CSR in addition to environmental strategies and by using eleven years of data rather than two. Russo and Fouts (1997) note that mature industries and growth industries differ with respect to organizational types and strategies. Firms have different resources and capabilities in different stages of the product life cycle and may implement differing strategies in the three different stages.

Thus, while the stage of the industry life cycle is likely to affect the relationship between CSR and CFP, the relationship has not yet been examined. The present study addresses the need to understand how this factor affects the CSR-CFP relationship, and in doing so attempts to shed light on the overall confusion surrounding the effects of CSR on CFP.

\section{$3 \quad$ Hypothesis development}

The underlying contingency factor for our hypotheses is that competitive dynamics are different in each stage of the industry life cycle. We begin with the earlier stages, introduction and growth, as barriers to entry are lower than in later stages (Agarwal, Sarka, and Echambadi, 2002; Argyres and Bigalow, 2007; Klepper, 1996; Robinson and McDougall, 2001). 
We see CSR as leading to positive CFP in the introductory stage of the industry life cycle. This stage is characterized by technological uncertainty, multiple competing technological paths, many potential adopters who are not familiar with the product, and relatively low entry barriers (Agarwal, Sarka, and Echambadi, 2002; Argyres and Bigalow, 2007; Klepper, 1996; Robinson and McDougall, 2001). Accordingly firms will strive to persuade the market their unique design is a viable solution to customer needs, and ideally demonstrate product superiority to establish it as a predominant, if not the dominant design. Both goals require innovation and commercialization capabilities (Utterback, 1994). Prior research indicates CSR enhances stakeholder relationships, and in particular customer relationships (Knox, Maklan, and French, 2005), which may align innovative efforts with market needs and foster commercialization capabilities. Accordingly CSR may enhance internal capabilities in the introductory stage of the industry life cycle.

In the context of market pioneering, Covin and Miles (1999) assert that first and early movers may be able to shape industry competitive dynamics and set a benchmark for followers. Extending this argument beyond product invention and commercialization, we believe the same outcome may hold for other firm capabilities such as CSR (Ditlev-Simonsen and Gottschalk, 2011). Therefore in addition to enhancing commercialization capabilities in the introductory stage, CSR programs may influence the competitive arena as these initiatives establish a benchmark for later CSR adopters.

There are fewer firms in the introductory stage than in the growth stage, and while entry occurs, the majority of competitors are resource constrained. Given that the market is characterized by product and adaptor uncertainty, firm resource allocation will prioritize product innovation. As a result only firms with excess resources will be able to implement CSR 
initiatives, which enhance the magnitude of the CSR-CFP effect in this stage of the ILC. In short, few firms will have the spare resources needed to focus on CSR, and fewer still will choose to do so, making it a relatively rare capability despite its known value.

These factors lead to our first hypothesis:

H1 The introduction stage of the industry life cycle positively moderates the CSR-CFP relationship.

During the growth stage entry barriers are still relatively low, as is the intensity of rivalry, but each factor is more significant to industry competitiveness and firm performance than in the introductory stage (Agarwal, Sarka, and Echambadi, 2002; Argyres and Bigalow, 2007; Klepper, 1996; Robinson and McDougall, 2001). The primary factor that buffers firms from more intense competition is market growth (Ferrier, 2001), which is by definition high during this stage of the industry life cycle. Lumpkin and Dess (2001) note that market opportunities are sufficiently high to allow multiple firms to succeed during the growth stage. Thus competitors are likely to have sufficient resources to attend to needs beyond those required for survival (Jawahar and McLaughlin, 2001). Competitors also face greater visibility, and thus a greater need to be seen as socially responsible to avoid the introduction of burdensome government regulation (Hull and Rothenberg, 2008; Miles, Munilla, and Covin, 2002, 2004). Therefore, during the growth stage more firms are able and more likely to allocate resources to activities beyond product innovation to include differentiation strategies such as CSR. They are also more likely to need to differentiate themselves from the competition as customer knowledge is higher than in the introductory stage, and customers are now more concerned with choosing a specific company's product on factors beyond basic functionality (McWilliams and Siegel, 2001; Surroca, Tribo, and Waddock, 2010). 
Firms in the growth stage of the life cycle will also learn from and imitate the strategies of their competitors who set the benchmark during the introductory stage as discussed above. Two outcomes result. Firstly, as imitation of successful differentiation strategies increases among all firms during the growth stage, firms that successfully implemented CSR strategies in the introduction stage will search for new factors to differentiate themselves: factors that will improve performance over prior differentiation tactics. Thus for firms with established CSR strategies their continued CSR activity at high levels may reduce performance as marginal costs exceed marginal benefits due to increased competition and increased imitation of their successful CSR strategies by their rivals. Secondly, firms that introduce CSR initiatives during the growth stage are imitating or replicating successful CSR initiatives of the CSR pioneering firms. Thus during the growth stage, CSR initiatives may not be a differentiating factor due to the number of CSR programs, and the number of alternative differentiating factors available to competitors that have higher rates of return. The competency of CSR is, in short, less rare and more imitable in the growth stage. This leads to our second hypothesis:

H2 The growth stage of the industry life cycle negatively moderates the CSR-CFP relationship.

The mature stage of the product life cycle is characterized by a new set of competitive conditions including high barriers to entry, an emphasis on process innovation, standardized products, economies of scale, dominant designs, a decrease in the number of competitors, and stabilizing market shares (Agarwal, Sarka, and Echambadi, 2002; Argyres and Bigelow, 2007; Klepper, 1996; Klepper and Graddy, 1990; Robinson and McDougall, 2001; St. John, Pounder, and Cannon, 2003). In this stage of the product life cycle smaller firms may seek market niches while large firms compete in standardized segments (Agarwal, Sarka, and Echambadi, 2002). 
A strategic implication is that differentiation should contribute to firm performance since differentiation lessens the impact of price competition, which is characteristic of this stage (Karlsson and Nystrom, 2003). Jawahar and McLaughlin (2001) think that strategies to deal with most stakeholders (excluding creditors) should be proactive rather than reactive during the mature stage. CSR may be the foundation of a market niche strategy. CSR regains viability as a strategic competency in this stage due to a decrease in the number of competitors and to a decrease in the differences among the products of competitors in the industry. Fewer competitors mean that fewer rivals will imitate this competency, making CSR rarer. And fewer product differences mean that the relative value of CSR, or any other remaining differentiating factor, is increased.

For other firms CSR may be a component of their effort to alter the competitive dynamics of the industry. In their discussion of political acumen, Russo and Fouts (1997) argue that firms which are regulatory compliant will act to impede increasing regulatory legislation, and thus will be less likely to embrace CSR. We believe firms with CSR capabilities will work to exceed compliance, and may even support new regulations as a competitive weapon to strengthen regulations and/or industry standards. Firms that can afford to pursue influence to increase the value of their CSR competency are likely to do so (Agarwal, Sarka, and Echambadi, 2002).

Thus, our mature-stage hypothesis:

H3 The mature stage of the industry life cycle positively moderates the CSR-CFP relationship.

With higher levels of munificence, firms have greater access to resources and growth opportunities (Keats and Hitt, 1988), meaning that pursuing any given means of differentiation, such as CSR, is less likely to draw resources away from functions critical to the survival of the 
firm. The RBV suggests that a company with resources to spare should develop new capabilities, such as CSR, which might become new core competencies (Surroca, Tribo, and Waddock, 2010). Munificence may affect the CSR-CFP relationship for more than one reason. First, while CSR is always available as an avenue to pursue, munificence increases the availability of other opportunities to differentiate, suggesting that other firms seeking to differentiate will be less likely to do so with CSR. Second, in a munificent environment customers may also be enjoying greater access to resources, making them able to afford to pay a premium for CSR rather than taking the lowest-priced alternative. Thus, in a munificent environment, CSR may effectively be valued more than it would be otherwise. Thus, CSR may be rarer under conditions of munificence, and it may also be more valuable.

When munificence is low, firms may lack the resources needed to pursue strategies beyond immediate survival. Thus lower munificence will not only inhibit firms from pursuing multiple strategies, but will steer these firms to strategies that focus on immediate firm survival subsistence rather than differentiation. It follows that CSR, a competency that lends itself to differentiation (Hull and Rothenberg, 2008), may be less valuable when munificence is low and firms are more focused on cost savings and survival.

Based on our discussion of CSR as a differentiating factor positively related to firm performance, our hypothesis concerning munificence is that:

H4 Higher levels of munificence positively moderate the CSR-CFP relationship.

The degree of environmental instability may also affect the CSR-CFP relationship. Instability arises from market changes (Dess and Beard, 1984) and technological changes (Sharfman and Dean, 1991), both of which may manifest their effect in terms such as increased competition, rapid process and/or product innovation, new entrants—including international 
competitors with differing competitive thrusts — changing consumer wants and demands, and so forth. CSR may help a firm with particular capabilities, as we discussed in the context of the firm's innovation capability in our discussion of the introductory stage of the product life cycle.

But CSR activity may be less useful when instability is due to multiple factors. The uncertainty of cause and effect and the rapidly changing environment will influence firm choice toward short-term survival and away from tactics such as CSR which offer more long-term rewards. If the future is uncertain, companies will play for the present. Lumpkin and Dess (2001) suggest that greater instability is associated with uncertainty and evokes a focus on survival. As previously argued this leads to prioritizing resource allocations to short-term survival policies over CSR initiatives. In some instances poor CSR behaviour may help a firm survive. For example our methodology defines poor CSR practice (concerns) to include workforce reductions, plant closings, environment regulatory conformity problems, and market behaviour related to collusion and antitrust. Yet these strategic decisions may be forced upon companies by the instability of the market, particularly when rapid changes force cost cutting and short-term solutions as the only clear way to guarantee a reasonable chance at immediate survival (Su, Xie, and Li, 2009). Instability pushes firms into short-term survival thinking. Shortterm survival strategies often include cost minimization, which encourages neglecting CSR. Thus under conditions of instability there are disincentives to CSR. Thus, our last hypothesis: H5 Higher levels of instability negatively moderate the CSR-CFP relationship.

\section{Methodology}

\subsection{Sample and data collection}

We collected our sample from Morgan Stanley Capital International (MSCI)'s Environmental, Social and Governance factors (ESG) database. The MSCI ESG indices are the continuation of 
indices developed over the past 20 years by Kinder, Lydenberg, and Domini (KLD). KLD was acquired by RiskMetrics in 2009, and MSCI acquired RiskMetrics in 2010. For each year beginning with 1991, the MSCI ESG provides a table of data with a collection of approximately 650 companies that comprise the Domini 400 Social SM Index and S\&P 500® with one record for each company and columns indicating membership of each index. Beginning in 2001, KLD expanded its coverage universe to include all companies on the Russell 1000®. In 2003, KLD added full coverage of the Russell $3000 ®$. This database includes seven major dimensions: Corporate Governance, Diversity, Employee Relations, Community, Environment, Human Rights, and Product. These seven dimensions are the original criteria that KLD used to evaluate companies' CSR, and they are the most cited in prior literature. KLD began to provide evaluation on other dimensions such as Alcohol and Gambling since 2002, which are still included in the MCSI ESG. These later dimensions were not included in our study both because most firms do not have such concerns, and because including them will greatly limit the time length of our longitudinal analysis. We thus only focus on the seven major dimensions as most CSR studies do. For some of the seven dimensions, a few items have changed since 1995. These include gay and lesbian policies in Corporate Governance, property, plant and equipment in Environment, and involvement in South Africa, Burma, and Mexico in Human Rights. We thus set our data collection period from 1996-2007 to avoid the unbalanced variance caused by different numbers of items within a dimension across time periods in panel data analysis. Two hundred thirty-nine firms with complete data were identified in this period.

We matched this dataset with financial data drawn from Compustat. Due to the limited Research and Development (R\&D) and Advertisement data attained from the dataset, the sample size was reduced to 45 firms with complete MSCI ESG and financial data. The final sample thus 
includes 495 entries with the 45 firms during an 11-year period (one year is reduced because some variables are one-year lagged).

\subsection{Measures}

\subsubsection{Corporate Social Responsibility (CSR)}

The CSR dimensions included in this study are Community Charity, Corporate Governance, Diversity, Employee Relations, Environment, Human Rights, and Product Quality and Safety. Based on these seven dimensions, we adopted the same composite measure as that employed by Hull and Rothenberg (2008). Their measure takes into account the number of each dimension's strengths and concerns, and thus, the dimensions with many distinct items receive proportionally greater weight than those with fewer items. This continuous index of CSR provides more information than the dummy variable as composed by McWilliams and Siegel (2000) and it can be more easily reproduced than the weighted index described by Waddock and Graves (1997), although the weights they describe appear to correspond well with this index. This CSR measure has been verified to produce results consistent with such prior studies as Waddock and Graves (1997) and McWilliams and Siegel (2000) and can thus be considered robust and reliable.

\subsubsection{Industry Life Cycle}

Strategic management papers have developed a variety of ways to operationalize industry life cycle stages (Agarwal, Sarka, and Echambadi, 2002; Hambrick and Lei, 1985; Kunkel, 1991; Lumpkin and Dess, 2001; McDougall, 1987; Miller and Camp, 1985; Robinson and McDougall, 1998; Sandberg, 1984, 1986). Among them, two approaches are consistently used to highlight the industry life cycle stages: industry growth rate (Hambrick and Lei, 1985; Hambrick, MacMillan and Day, 1982; Hofer, 1977; McDougall, 1987; Miller and Camp, 1985) and product 
differentiation (Kunkel, 1991; McDougall, 1987; Robinson and McDougall, 1998; Sandberg, 1984, 1986). Following Robinson and McDougall (1998), we incorporate both approaches. As shown in Table 1, we use the advertising intensity ratio (i.e., advertising expenditures divided by sales revenue) and the annual industry growth rate to approximate the product differentiation and industry growth, respectively.

Table 1 shows how advertising intensity and industry growth rate differ across the industry life cycle stages. When advertising intensity ratio is high (i.e., above 1\%) and industry growth rate is relatively low (i.e., lower than $10 \%$ ), the industry is striving to advertise its products or services to kick off market growth - often characterizing the introduction stage. When advertising intensity ratio is high (i.e., above $1 \%$ ) and industry growth rate is high (i.e., above $10 \%$ ), the industry has finally taken off and is enjoying the growth stage. Such a growth stage can last into the combination of a moderate advertising intensity and high growth rate, meaning that the industry is still enjoying high growth even without the support of advertising. After this stage, the industry will typically move to the maturity stage, which is characterized by moderate advertising intensity $(0.5 \% \sim 1 \%)$ and relatively low industry growth rate (lower than $10 \%$ ), which indicates that even moderate advertising intensity cannot support a high growth rate and the market is winding down; or is characterized by low advertising intensity (i.e., lower than $0.5 \%$ ), which is often a clear sign of the mature stage when the product and service are highly homogeneous and advertising expense is significantly decreased. The last stage, decline stage with low advertising intensity (i.e., lower than $0.5 \%$ ) and low industry growth rate (i.e., lower than $10 \%$ ) which indicate a dying market, has rarely been found in previous studies - most industries can regenerate themselves or abandon dying features before actual death. Thus, we do not include this stage. We have coded three dummy variables, with a "1" in each indicating the 
introduction, growth, and maturity stages respectively, and " 0 " indicating one of the other stages.

\subsubsection{Industry Effect}

Our sample is composed of firms in a variety of industries, and financial performance can be affected by industry growth rate and the instability of such a growth rate (Dess and Beard, 1984). The munificence of a high-growth industry can make up for low organizational slack or other weaknesses, allowing firms to more easily adopt a fast pace of CSR or engage CSR in multiple dimensions. But firms in industries with unstable growth rates may need to preserve their resources against future scarcity, and spend fewer resources on CSR activities. Following Palmer and Wiseman (1999), we calculated the three-year moving average of industry sales growth rate by using Compustat data, with industry identified by the first three SIC digits. This average is used to approximate industry munificence. We then calculated the standard deviation of the sales growth rate for the previous three years to approximate industry instability.

\subsubsection{Performance}

As do most studies in this field, and in order to be able to compare with prior results, we employed Return on Assets (ROA) in this study to measure CFP.

We also controlled for the following variables that have been verified to affect the CSRCFP relationship.

\subsubsection{Slack}

Organizational slack is "a cushion of actual or potential resources which allow an organization to adapt successfully to internal pressures for adjustment or to external pressures for change in 
policy, as well as to initiate changes in strategy with respect to the external environment" (Bourgeois, 1981, p. 30). Slack has a positive impact on social performance (Bowen, 2002; Sharma, 2000). The more slack resources a firm has, the more it can spare for CSR activities and the more easily it can engage multiple CSR dimensions. We controlled for last year's organizational slack by including the ratio of long-term debts to total capital in our model (Chatterjee, 1990; Reuer and Ragozzino, 2005; Singh, 1986). The smaller the ratio, the less need for a firm to seek external funding, which implies that it has more slack. This ratio is thus an inverse measure of organizational slack.

\subsubsection{Research and Development Investment $(R \& D)$}

$R \& D$ has been recently verified as an important contingent factor that affects the CSR-CFP relationship (Hull and Rothenberg, 2008; McWilliams and Siegel, 2000). R\&D activities can compete for limited resources with CSR activities. More importantly, R\&D investment potentially enhances an organization's ability to differentiate itself from competitors and thus undermines the need to invest in CSR as a differentiation factor. Because R\&D is highly correlated with CSR, it is difficult to measure the effects of CSR in highly innovative companies. Thus CSR most strongly and visibly affects firm performance in low-innovation firms (Hull and Rothenberg, 2008). We included last year's R\&D investments weighted by firm total assets to control for such an effect in our model.

\subsubsection{Advertisement Expenses}

Advertisement expenses also heavily affect CSR engagement (Hull and Rothenberg, 2008). Advertisement expenses are similar to R\&D expenses in that they do not just highlight the 
different stages of the industry life cycle. Advertisement expenses also indicate the differentiation features of the company's product. Typically a highly differentiated product undermines the need for using CSR engagement as a differentiation factor. We thus control last year's ratio of advertisement expenses to net sales in our analysis.

\subsubsection{Firm Size}

Larger firms may have stronger motives to engage in CSR activities. They may want to lead the industry or to avoid becoming a target for government regulations or NGO activities. Larger firms may also be better able than smaller firms to handle complicated CSR engagement as they are more familiar with diversified operations. We thus controlled for the logarithm of total assets in our model to control the effects of firm size.

\section{Analysis and Results}

Means, standard deviations, and correlations are included in Table 2. It shows that ROA has a slightly negative relationship with the introduction stage $(\mathrm{r}=-.02, p>.05)$, a positive relationship with the growth stage $(\mathrm{r}=.20, p<.05)$, and a negative relationship with the mature stage $(\mathrm{r}=-.16, p<.05)$. These findings are consistent with previous studies (Agarwal, Sarka, and Echambadi, 2002) and thus support the logic of our measurement model. Second, we found that the three stages correlate with each other, but the correlation between introduction and growth is the lowest $(\mathrm{r}=-.15, p<.05)$. Those between introduction and mature $(\mathrm{r}=-.53, p<$ $.05)$ and growth and mature $(r=-.75, p<.05)$ are notably higher. Because of the mutual exclusiveness, we can only control two of the three variables in regression. We control introduction and growth because they are correlated at a low level and less likely to generate multicollinearity problems in the analysis. 
Table 3 summarizes the panel data analysis results. We applied GLS fixed-effects (FE) model to estimate the hypothesized relationships. We choose the fixed-effects model because we have no reason to assume that there may be omitted individual specific effects uncorrelated with the independent variables included in our model. Although random-effects (RE) model can produce more efficient estimates, the fixed-effects model, in this case, can give more conservative estimates.

Model 1 only includes all contingent variables, including moderators, to control their possible effects on ROA. It shows that last year's R\&D has a negative relationship with ROA (B $=-68.70, p<.001)$, indicating that the positive effect of $\mathrm{R} \& \mathrm{D}$ may take longer than a year to take place. Industry growth has a positive relationship with $\mathrm{ROA}(\mathrm{B}=26.90, p<.001)$ and industry volatility has a negative relationship with $\operatorname{ROA}(\mathrm{B}=-8.90, p<.05)$. These findings are in alignment with previous findings (Dess and Beard, 1984) and thus support the validity of our measures. Both the introduction stage and growth stage have positive but non-significant relationships with $\mathrm{ROA}$ (introduction: $\mathrm{B}=.74, p>.05$; growth: $\mathrm{B}=1.23, p>.05$ ).

Model 2 includes CSR, which has a marginally significant relationship with ROA $(\mathrm{B}=$ $.20, p<.1$ ), indicating a negative effect of CSR on ROA. Model 3 further includes the interaction items of CSR and the introduction stage. It shows that CSR*Introduction has a positive relationship on $\mathrm{ROA}(\mathrm{B}=.80, p<.05)$. Thus $\mathrm{H} 1$ is supported. Model 4 includes the interaction item, CSR ${ }^{*}$ Growth, which has a significantly negative relationship with $\mathrm{ROA}(\mathrm{B}=$ $.59, p<.05)$. Thus $\mathrm{H} 2$ is supported. Model 5, instead of including CSR ${ }^{*}$ Growth, includes the interaction items of CSR and the mature stage. It shows that CSR*Maturity has a positive yet non-significant relationship on $\mathrm{ROA}(\mathrm{B}=.27, p>.05)$. Thus $\mathrm{H} 3$ is not supported. Model 6 , instead of including the interaction items of CSR and life cycle stages, includes the interaction 
items of CSR and industry munificence and instability. It shows that CSR*Munificence has a negative but insignificant relationship with $\mathrm{ROA}(\mathrm{B}=-.19, p>.05)$ and CSR*Instability has a negative and significant relationship with $\mathrm{ROA}(\mathrm{B}=-2.76, p<.05)$, which supports $\mathrm{H} 5$, but not H4.

\section{Conclusion}

This study broadens our understanding of the CSR-CFP relationship by applying the contingency perspectives of industry life cycle, munificence, and instability to the insights offered by the RBV. We find support for the moderating effect of the industry life cycle during the introductory and growth stages. Instability is found to affect CSR-CFP, while munificence is not. Prior research that presents contradictory results in the study of the complex CSR-CFP relationship did not control for the industry life cycle factor, and only some research included instability and munificence. The results of the present study, in which CSR positively and negatively affects CFP under different environmental conditions, may be a step toward understanding earlier, conflicting results and the CSR-CFP relationship itself.

But this study does not resolve the CSR-CFP relationship. It is limited in that we only considered companies for which complete data were available for the full period of the study. The study did not consider the implications of munificence and/or instability during the product life cycle stages. Sharfman and Dean (1991) indicate any stage of the industry life cycle could be characterized by differing degrees of munificence and instability. Thus it is possible that all industries in the growth stage, for example, encounter dissimilar competitive dynamics as a result of munificence and/or instability levels. Finally, as Schreck (2011) notes, different components of CSR may affect CFP differently; their relationships with CFP may also be 
affected differently by different stages of the industry life cycle or levels of munificence or instability. Though we did not disaggregate CSR in this study, we hope to see a study that does.

Future studies may overcome these limitations. But there are other avenues to move us toward a better understanding of the role of CSR. One possible direction for study would be to examine how a company goes about engaging in CSR - looking at the specific nature of that engagement process. Since both the industry life cycle and degree of instability moderate the CSR-CFP relationship, there might be accompanying differences in the derivation and implementation of CSR programs. This would allow us to further clarify the conditions under which CSR could have its maximum effect on CFP.

We found significant support for the introductory stage having a positive effect on the CSR-CFP relationship, and for growth having a negative effect on the CSR-CFP relationship. Our results with respect to the effects of the mature stage on the CSR-CFP relationship were consistent, in terms of direction, with our hypothesis, but not statistically significant. These results suggest further study of this potential relationship. Though our findings do not provide significant support for the mature stage having a positive effect on the CSR-CFP relationship, we believe that this relationship deserves further study before being dismissed. Our findings do suggest, however, that CSR is most likely to help firm performance in the introductory stage and to hurt it in the growth stages of an industry life cycle. It follows that CSR can be expected to have a more positive effect on firm performance in the mature stage than in the growth stage. This finding may be of use to managers who want to know the most effective time to pursue CSR, and it may also be of use to CSR researchers seeking to resolve the question of whether or when - CSR helps CFP. Doing good may always be its own reward, but apparently sometimes it leads to doing well and sometimes it does not. Though this study does not address 
the timing of CSR initiatives, it would doubtless be instructive to examine the starting and ending points of CSR activities with respect to industry life cycle. Do CSR initiatives that start in the introductory stages - which our data suggest is the best time to engage in CSR - carry their financial benefits forward through other stages if maintained consistently? Is the negative effect we observed due to latecomers to CSR being penalized while those who engaged in CSR early corner the market on the benefits of CSR? Or does the ebb tide in the growth stage lower all boats, meaning that those who did CSR in the introductory stage and those who did not see the same reduction in the CSR-CFP relationship once growth sets in? We hope to see these questions addressed soon.

We were surprised to see that munificence does not appear to affect the CSR-CFP relationship. Apparently, the value of CSR is relatively constant under different levels of resource availability, suggesting that companies will do well to invest in CSR whenever they can, regardless of the relative ease with which competitors will or will not be able to pursue it as well. This suggests that a core competency may, under some circumstances, not need to be scarce or inimitable so long as it is valuable. Exploring this possibility is beyond the scope of the present study but might yield results of significance to RBV theory.

Knowing that CSR benefits CFP most in a setting of high stability (or low dynamism/instability) is useful to both managers and researchers. This knowledge may help clarify the scholarly debate about the financial merits of CSR, and give managers a better sense of the circumstances under which they will get the most financial benefit from an investment in CSR - the more stable the industry, the more profitable an investment in CSR will prove. However, given that the value of CSR is a long-term benefit, managers confident about longterm firm survival may invest in advance of anticipated future stability. 
Using the RBV perspective supported by the contingency perspective, we were able to clarify the relationship between CSR and CFP. It appears that to maximize the financial benefits of CSR, managers should invest in CSR primarily during the introductory stage of the industry or whenever instability is low. Investment in CSR seems to be least helpful to the bottom line during growth, and new CSR initiatives should perhaps be postponed during the growth stage and launched when the industry reaches maturity. It would seem that if a company wants to do well by doing good, it should pay careful attention to when and under what circumstances it does good. In the introductory stage of the life cycle, the mature stage of the life cycle, or at any point when stability is expected, a company is best advised to invest in CSR in order to maximize profits. 


\section{References}

Agarwal, R., Sarkar, M. B. and Echambadi, R. (2002) 'The conditioning effect of time on firm survival: An industry life cycle approach', Academy of Management Journal Vol. 45, No. 5, pp.971-994.

Agarwal, R. and Bayus B. L. (2004) 'Creating and surviving in new industries', in Baum J. A. C. and A. M. McGahan, A. M. (Eds.), Business Strategy over the Industry Lifecycle (Advances in Strategic Management, Volume 21), Emerald Group Publishing Limited, pp.107-130.

Argyres, N. and L. Bigelow, L. (2007) 'Does transaction misalignment matter for firm survival at all stage of the industry life cycle?', Management Science, Vol. 53, No. 8, pp.13321344.

Barney, J. (1991) 'Firm resources and sustained competitive advantage', Journal of Management, Vol. 17, No. 1, pp.99-120.

Becchetti, L., Di Giacomo, S. and Pinnacchio, D. (2008) 'Corporate social responsibility and corporate performance: Evidence from a panel of us listed companies', Applied Economics, Vol. 40, pp.541-567.

Bourgeois L. J. III. (1981) 'On the measurement of organizational slack'. Academy of Management Review, Vol. 6, pp.29-40.

Bowen, F. (2002) 'Does size matter? Organizational slack and visibility as alternative explanations for environmental responsiveness'. Business and Society, Vol. 41, pp.118124.

Branco, M. C. and Rodrigues, L. L. (2006) 'Corporate social responsibility and resource-based perspectives', Journal of Business Ethics, Vol. 69, pp. 111-132.

Carroll, A. B. and Shabana, K. M. (2010) 'The business case for corporate social responsibility: A review of concepts, research and practice', International Journal of Management Reviews, Vol. 12, No. 1, pp.85-105.

Chatterjee, S. (1990) 'Excess resources, utilization costs, and mode of entry'. Academy of Management Journal, Vol. 33, pp.780-200.

Covin, J. G. and Miles, M. P. (1999) 'Corporate entrepreneurship and the pursuit of competitive advantage: Entrepreneurship theory and practice', Entrepreneurship Theory and Practice, Vol. 23, No. 3, pp.47-63.

Dess, G. and Beard, D. (1984) 'Dimensions of organizational task environments', Administrative Science Quarterly, Vol. 29, pp.52-73.

Ditlev-Simonsen, C. D. and Gottschalk, P. (2011) 'Stages of growth model for corporate social responsibility', International Journal of Corporate Governance, Vol. 2, No.3/4, pp. 268 287. 
Ferrier, W. J. (2001) 'Navigating the competitive landscape: The drivers and consequences of competitive aggressiveness', Academy of Management Journal, Vol. 44, No. 4, pp.858$\underline{877 .}$

Ganco, M. and Agarwal, R. (2008) 'Performance differentials between diversifying entrants and entrepreneurial start-ups: A complexity approach', Academy of Management Review, Vol. 34, No. 2, pp.228-252.

Hambrick, D. C. and Lei. D. (1985) 'Toward an empirical prioritization of contingency variables for business strategy', Academy of Management Journal, Vol. 28, pp.763-788.

Hambrick, D. C., MacMillan, and D. L. Day, D. L. (1982) 'Strategic attributes and performance in the BCG matrix: A PIMS-based analysis of industrial product businesses', Academy of Management Journal, Vol. 25, pp.510-531.

Harris, R. D. (2004) 'Organizational task environments: An evaluation of convergent and discriminant validity', Journal of Management Studies, Vol. 41, No. 5, pp.857-882.

Hofer, C. W. (1975) 'Toward a contingency theory of business strategy', Academy of Management Journal, Vol. 18, pp.784-810.

Hofer, C. W. (1977) Conceptual Constructs for Formulating Corporate and Business Strategy. Harvard Intercollegiate Case Clearing House, Boston, MA.

Hull, C. E. and S. Rothenberg, S. (2008) 'Firm performance: The interactions of corporate social performance with innovation and industry differentiation', Strategic Management Journal, Vol. 29, pp.781-789.

Jawahar, I. M. and McLaughlin, G. L. (2001) 'Towards a descriptive stakeholder theory: An organizational life cycle approach’, Academy of Management Review, Vol. 26, no. 3, pp.397-414.

Karlsson, C. and Nystrom, K. (2003) 'Exit and entry over the product life cycle: Evidence from the Swedish manufacturing industry', Small Business Economics, Vol. 21, No. 2, pp.135144.

Keats, B. W. and Hitt, M. A. (1988) 'A causal model of linkages among environmental dimensions, macro organizational characteristics and performance', Academy of Management Journal, Vol. 31, No. 3, pp.570-598.

Klepper, S. (1996) 'Exit, entry, growth and innovation over the product life cycle', The American Economic Review, Vol. 86, No. 3, pp.562-583.

Klepper, S. and Grady, E. (1990) 'The evolution of new industries and the determinants of market structure', Rand Journal of Economics, Vol. 21, No. 1, pp.27-44.

Knox, S., Maklan, S. and French, P. (2005) 'Corporate social responsibility: Exploring stakeholder relationships and programme reporting across leading FTSE companies', Journal of Business Ethics, Vol. 61, No. 1, pp.7-28. 
Kunkel, S. W. (1991) 'The impact of strategy and industry structure on new venture performance', unpublished doctoral dissertation, University of Georgia.

Lee, M. D. P. (2008) 'A review of the theories of corporate social responsibility: Its evolutionary path and the road ahead', International Journal of Management Reviews, Vol. 10, No. 1, pp.53-73.

Lee, G. K. (2009) 'Understanding the timing of 'fast-second' entry and the relevance of capabilities in invention vs. commercialization', Research Policy, Vol. 38, pp.86-95.

Lockett, A., Moon, J. and Visser, W. (2006) 'Corporate social responsibility in management research: Focus, nature, salience and sources of influence', Journal of Management Studies, Vol. 43, No. 1, pp.115-136.

Lumpkin, G. T. and Dess, G. G. (2001) 'Linking two dimensions of entrepreneurial orientation to firm performance: The moderating role of environment and industry life cycle', Journal of Business Venturing, Vol. 16, pp.429-451.

Margolis, J. D. and Walsh J. P. (2003) 'Misery loves companies: Rethinking social initiatives by business', Administrative Science Quarterly, Vol. 48, No. 2, pp.268-305.

McArthur, A. W. and Nystrom, P. C. (1991) 'Environmental dynamism, complexity and munificence as moderators of strategy-performance relationships', Journal of Business Research, Vol. 23, pp.349-361.

McDougall, P. P. (1987) 'An analysis of strategy, entry barriers, and origin as factors explaining new venture performance', unpublished doctoral dissertation, University of South Carolina.

McWilliams, A. and Siegel, D. S. (2000) 'Corporate social responsibility and financial performance: Correlation or misspecification', Strategic Management Journal Vol. 21, No. 5, pp.603-609.

McWilliams, A. and Siegel, D. S. (2001) 'Corporate social responsibility: A theory of the firm perspective', Academy of Management Review, Vol. 26, No. 1, pp.117-127.

McWilliams, A., Siegel, D. S. and Wright, P. M. 2006, 'Corporate social responsibility: Strategic implications', Journal of Management Studies, Vol. 43, No. 1, pp.1-18.

Miles, M. P., Munilla, L. S. and Covin, J. G. (2002) 'The constant gardener revisited: The effect of social blackmail on the marketing concept, innovation, and entrepreneurship', Journal of Business Ethics, Vol. 41, No. 3, pp.287-295.

Miles M. P., Munilla, L. S. and Covin, J. G. (2004) 'Innovation, ethics, and entrepreneurship', Journal of Business Ethics, Vol. 54, No. 1, pp.97-101.

Miller, A. and Camp, B. (1985) 'Exploring determinants of success in corporate ventures', Journal of Business Venturing, Vol. 1, pp.87-105. 
Orlitzky, M., Schmidt, F. L. and Rynes, S. L. (2003) 'Corporate social and financial performance: A meta-analysis’, Organization Studies, Vol. 24, No. 3, pp.403-441.

Palmer, T. B. and Wiseman, R. M. (1999) 'decoupling risk from income stream uncertainty: a holistic model of risk', Strategic Management Journal, Vol. 20, pp.1037-1062.

Reuer, J., and Ragozzino, R. (2005) 'Agency hazards and alliance portfolios'. Strategic Management Journal. Vol. 27, pp.27-43.

Robinson, K. C. and McDougall, P. P. (1998) 'The impact of alternative operationalization of industry structural elements on measures of performance for entrepreneurial manufacturing ventures', Strategic Management Journal, Vol. 19, pp.1079-1100.

Robinson, K. C. and McDougall, P. P. (2001) 'Firm barriers and new venture performance: A comparison of universal and contingency approaches', Strategic Management Journal, Vol. 22, No. 6/7, pp.659-685.

Russo, M. V. and Fouts, P. A. (1997) 'A resource-based perspective on corporate environmental performance and profitability’, Academy of Management Journal, Vol. 40, No. 3, pp.534559.

Sandberg, W.R. (1984). 'The determinants of new venture performance: Strategy, industry structure, and entrepreneur', unpublished doctoral dissertation, University of Georgia.

Sandberg, W. R. (1986). New Venture Performance: The Role of Strategy and Industry Structure. Lexington Books, Lexington, MA.

Sharfman, M. P. and Dean, J. W. (1991) 'Conceptualizing and measuring the organizational environment: A multidimensional approach', Journal of Management, Vol. 17, No. 4, pp.681-700.

Schreck, P. (2011) 'Reviewing the business case for corporate social responsibility: New evidence and analysis.' Journal of Business Ethics, Vol. 103, pp.167-188.

Sharma, S. (2000) 'Managerial interpretations and organizational context as predictors of corporate choice of environmental strategy'. Academy of Management Journal, Vol. 42, pp.681-697.

Singh, J.V. (1986) 'Performance, slack, and risk taking in organizational decision making'. Academy of Management Journal, Vol. 29, pp.562-285.

St John, C. H., Pounder, R. W. and Cannon, A. R. (2003) 'Environment uncertainty and productprocess life cycles: A multi-level interpretation of change over time', Journal of Management Studies, Vol. 40, No. 2, pp.513-541.

Su, Z., Xie, E. and Li, Y. (2009) 'organizational slack and firm performance during institutional transitions', Asia Pacific Journal of Management, Vol. 26, pp.75-91. 
Surroca, J., Tribo, J. A. and Waddock, S. (2010) 'corporate responsibility and financial performance: The role of intangible resources', Strategic Management Journal, Vol. 31, pp.463-490.

Utterback, J. M. (1994) Mastering the Dynamics of Innovation, Harvard Business School Press, Boston, MA.

Vanhamme, J. and Grobben, B. (2009) '"Too good to be true!". The effectiveness of CSR history in countering negative publicity', Journal of Business Ethics, Vol. 85, pp.273-283.

Waddock, S.A., and Graves, S.B. (1997) 'The corporate social performance-financial performance link', Strategic Management Journal, Vol. 18, pp.303-319.

Wood, D. J. (2010) 'Measuring corporate social performance: A review', International Journal of Management Reviews, Vol. 12, No. 1, pp.50-84.

Wood, D. J. and Jones, R. E. (1995) 'Stakeholder mismatching: A theoretical problem in empirical research on corporate social performance', International Journal of Organizational Analysis Vol. 3, No. 3, pp.229-267. 
Table 1 Industry life cycle classification system

\begin{tabular}{|l|c|c|c|}
\hline & & \multicolumn{2}{|c|}{ Industry Sales Growth Rate } \\
\hline & & $>=10 \%$ & $<10 \%$ \\
\hline \multirow{2}{*}{$\begin{array}{l}\text { Advertising } \\
\text { Intensity }\end{array}$ Ratio } & $>=1 \%$ & Growth & Introduction \\
\cline { 2 - 4 } & $0.5 \sim 1 \%$ & Growth & Maturity \\
\cline { 2 - 4 } & $<0.5 \%$ & Maturity & Decline \\
\hline
\end{tabular}

